\title{
Interaction Between a Lateritic Soil and a Non-woven Geotextile in Different Moisture Conditions
}

\author{
Gabriel Steluti Marques*t and Jefferson Lins da Silva ${ }^{\dagger}$ \\ Laboratory of Geosynthetics, Department of Geotechnical Engineering, São Carlos School of Engineering, University of São
} Paulo, São Carlos, Brazil

This work evaluates the increase in stiffness provided by the variation of moisture content (matrix suction) and the grain size structure at the interface between a cohesive tropical soil (lateritic clay) and a non-woven geotextile. For this purpose, monotonic pullout tests with soil suction monitoring were performed on small-sized equipment under three scenarios ("O" Optimum, "D" Dry and "DP" Dry Post-Compaction) and two vertical pressures (14 and $28 \mathrm{kPa}$ ). The Dry Post-Compaction tests were conducted with the same matrix suction of the Dry tests. The monotonic pullout tests evaluated the soil-geosynthetic interaction under constant displacement to calculate the apparent confined stiffness of the geosynthetic (Jc). The Wide Width Tensile tests were conducted to assess the unconfined stiffness of the non-woven geotextile (Jn). The Dry scenario, compacted with higher compaction energy than the others and, consequently, altering its grain size structure, presented the best performance. This indicates that other parameters besides the suction may be influencing the interaction between the soil and the non-woven geotextile. Even under small vertical pressures, the apparent confined stiffness improves considerably compared to the unconfined stiffness. This indicates that the use of the unconfined stiffness obtained by index tests may be a conservative measure in paving projects.

Gabriel Steluti Marques orcid.org/0000-0002-6713-2425

Jefferson Lins da Silva orcid.org/0000-0002-2226-4950

Specialty section:

This article was submitted to Transportation and Transit Systems,

a section of the journal

Frontiers in Built Environment

Received: 19 August 2019 Accepted: 25 June 2020

Published: 16 July 2020

Citation:

Marques GS and Lins da Silva J (2020) Interaction Between a Lateritic Soil and a Non-woven Geotextile in Different Moisture Conditions.

Front. Built Environ. 6:116. doi: 10.3389/fbuil.2020.00116

\section{INTRODUCTION}

In recent years, the search for alternative materials in infrastructure works has been increasing rapidly once the exploration of natural deposits and the extraction of relevant materials are onerous services, especially in places where this material is scarce resulting in high transport distances (Vilar and Bueno, 2008).

In tropical countries, there are abundant natural materials known as lateritic soils, normally classified as inappropriate material for pavement purposes by many soil classification systems based on the grain size distribution and soil consistency (Villibor et al., 2009). However, the tropical climate intensifies the process of leaching and chemical weathering of the soil, which accumulates in a considerable amount of iron and aluminum oxides providing high load-bearing capacity and low expansibility (Nogami and Villibor, 1981).

Another alternative material available to control the pathological manifestation, which increases the service life of the pavement and reduces the thickness of the base layer, is the geosynthetic. The non-woven geotextile was one of the first geosynthetics used in paving as reinforcement. However, 
with the emergence of geogrids, the non-woven geotextiles have been mostly used as a drainage material. This can be explained by its high deformation and, consequently, low stiffness modulus in unconfined tests. However, the non-woven fabric exhibits a high increase in stiffness in confined situations and can become an economic alternative as a reinforcement.

In order to ensure a good performance of the reinforced structure, efficient interaction between the geosynthetic and the base material is necessary, increasing the lateral confinement and the stiffness of the system. Thus, the stiffness modulus of the system under low deformation often becomes a more representative parameter of the soil-geosynthetic interaction than the maximum pullout resistance (Chang et al., 1998).

This work evaluates the increase in stiffness provided by the variation of moisture content (matrix suction) and the grain size structure at the interface between a cohesive tropical soil (lateritic clay) and a non-woven geotextile. For this purpose, monotonic pullout tests with soil suction monitoring were performed on small-sized equipment under three scenarios ("O" Optimum, "D" Dry, and "DP" Dry Post-Compaction) and two vertical pressures (14 and $28 \mathrm{kPa}$ ). The Dry Post-Compaction tests were conducted with the same matrix suction of the Dry tests. The monotonic pullout tests evaluated the soil-geosynthetic interaction under constant displacement to calculate the apparent confined stiffness of the geosynthetic (Jc). The Wide Width Tensile tests were conducted to assess the unconfined stiffness of the non-woven geotextile (Jn). Although there is no general rule in the literature that specifies how best to obtain the complex confined stiffness parameter of a geosynthetics, this paper aims to contribute to making the choice of the most suitable scenario for the studied soil and to compare the confined and unconfined stiffness of the non-woven geotextile.

\section{MATERIALS AND METHODS}

\section{Soil and Geotextile Properties}

In order to use a soil with tropical characteristics, a clayey tropical soil was chosen, classified as a silt of high plasticity (MH), according to the Unified Soil Classification System (USCS). This material was collected near the city of São Carlos, São Paulo, Brazil.

The predominantly clayey soil has approximately $70 \%$ fines, with $\mathrm{D}_{50}=0.007 \mathrm{~mm}$ and $\mathrm{D}_{M a z}=0.6 \mathrm{~mm}$. The soil has a California Bearing Ratio (CBR) of $22 \%$ and expansion of $0.02 \%$.

The use of local fine soils in their natural or even stabilized condition requires a more detailed study of their geotechnical properties. For this reason, in order to know the applicability of this soil in pavement structures, we used the MCT (Miniature, Compacted, Tropical) methodology, which addresses a different methodology for tropical soils, proposed by Nogami and Villibor (1981). Based on these results, the soil was classified as a Clayey Lateritic (LG'), which can be used in the base of lowcost pavements.

The non-woven geotextile is needled with continuous filaments and composed by polyester (PET). The results of the Wide-width tensile test showed a maximum tensile strength of $33.48 \mathrm{kN} / \mathrm{m}$ (catalog strength of $30 \mathrm{kN} / \mathrm{m}$ ) and average deformation at rupture of $61.20 \%$. The average stiffness modulus for a deformation of 2 and 5\% was 104.40 and $77.50 \mathrm{kN} / \mathrm{m}$, respectively.

\section{Scenario Definition}

Table 1 summarizes the initial and final molding conditions during the preparation of the test box prior to testing. All scenarios were tested with a compaction degree (GC) of $98 \%$. The Optimum Scenario "O" has an estimated test suction of $15 \mathrm{kPa}$, while the Dry Scenario "D" and the Dry Post-compaction Scenario "DP" presented suctions of $75 \mathrm{kPa}$.

Figure 1 illustrates the representation and trajectories of the three molding condition points in the soil compaction curve. It is noted that the "O" and "DP" scenarios are compacted at the same point, but only the "O" condition remains at this point for the pull-out tests, whereas the "DP" scenario would lose moisture (DP trajectory) until it reaches the same moisture content of the "D" scenario. The dry "D" scenario was tested at the same point as "DP" with similar suctions at the time of testing. However, in order to achieve a test condition at the same compaction degree as the "DP" condition, the test had to be subjected to higher compaction energy (Trajectory D), which provided a more flocculated soil structure.

\section{Pullout Apparatus}

The pullout tests were performed for different suctions, which required more precise control of soil moisture content and the use of a constant soil drying temperature. For this reason, we opted to use a small box.

Although ASTM D 6706-01 (2013) specifies dimensions larger than those in the small box, Kakuda (2005) demonstrated a good performance of this box to use cohesive soils in monotonic pullout tests. After that, research was carried out using this equipment, emphasizing Ferreira (2007), who compared the confined stiffness between different geogrids and Pereira (2010) that evaluated the pullout resistance of a geogrid under different moisture conditions.

The small-sized equipment consists of a rigid steel box with inner dimensions of $24.5 \mathrm{~cm}$ long, $30 \mathrm{~cm}$ wide and $14.5 \mathrm{~cm}$ high (Figure 2). The upper surface has a reaction cap coupled to a pressure-controlled air bag for the application of the overload. In the rear region, there is a support for the fitting of four tell-tales, which are connected to the geosynthetic by inextensible wires.

There are two holes on the side of the box with a diameter of $7 \mathrm{~mm}$ in which it was possible to insert a tensiometer to check the interstitial water pressures developed in the cohesive soil during the pullout test. The tensiometer was installed just $1.0 \mathrm{~cm}$ below the soil-reinforcement interface.

The displacements of the non-woven geotextile were measured in four different points nominated D1, D2, D3, and D4. The Geotextile was confined $210 \mathrm{~mm}$ long and $260 \mathrm{~mm}$ transverse inside the box (Figure 2). All points were spaced $45 \mathrm{~mm}$ longitudinally from each other and only the D2 and D3 (central) sensors were used in the present analysis in order to minimize the effects of the edges in the apparent confined stiffness calculations. 
TABLE 1 | Initial and final molding conditions.

\begin{tabular}{|c|c|c|c|c|c|}
\hline Scenario & W Compacted (\%) & W tested $(\%)$ & Degree of Compaction DC (\%) & $\rho \operatorname{dmax}\left(\mathrm{g} / \mathrm{cm}^{3}\right)$ & Estimated Suction (kPa) \\
\hline 0 & 22.75 & 22.75 & 98 & 1.593 & 15 \\
\hline$D$ & 18.75 & 18.75 & 98 & 1.593 & 75 \\
\hline DP & 22.75 & 18.75 & 98 & 1.593 & 75 \\
\hline
\end{tabular}

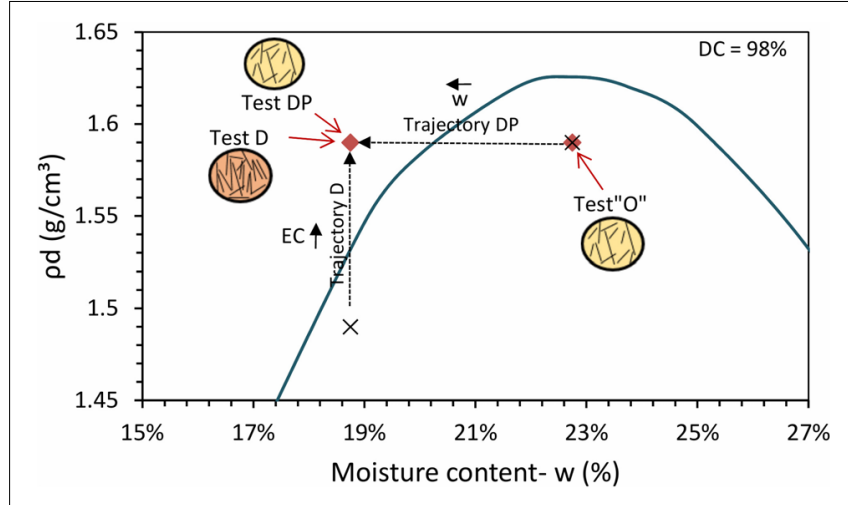

FIGURE 1 | Illustration of the trajectories and study points of the "O", "D," and "DP" scenarios in the compaction curve.



In order to inhibit the yielding effect of the non-woven geotextile, provided by the high deformation of the geotextile in the unconfined region between the box and the traction grab, a reinforcement for the geosynthetic was performed along this range. For this, on the surface of the non-woven geotextile up to $20 \mathrm{~mm}$ inside the box, epoxy glue was used, superimposed by a plastic blanket on the upper and lower surfaces of the geosynthetic. Figure 3 illustrates the exhumation of pilot tests performed with and without reinforcement in the unconfined region of the non-woven geotextile. The importance of the reinforcement in the unconfined region can be observed since the reduction of the confined area by the yielding effect was completely minimized.

\section{Test Procedure}

The monotonic pullout test was performed according to the procedures described in ASTM D 6706-01 (2013). The applied loads were 14 and $28 \mathrm{kPa}$ having as a limiting factor the maximum resistance of the non-woven geotextile in the wide-width tensile test. Larger confining stresses would result in ruptures of the geotextile in the unconfined region before the pullout occurs. These overloads are in the order of values usually found in the literature (Ferreira et al., 2008) which represent the tensions acting on the layers of the base and sub-base of pavements.

The tests started only after stabilizing the tensiometer readings with an average time of $5 \mathrm{~min}$. The pullout speed adopted was $1.0 \mathrm{~mm} / \mathrm{min}$.

For the tests in the "DP" scenario, the box, where all the soil was compacted, was placed inside the oven at a constant temperature of $30^{\circ} \mathrm{C}$, so as to simulate drying at room temperature and temperatures commonly found in the interior of the floor structure. The moisture loss was controlled through the initial mass of the box in relation to the final weight at the time of weighing.

After the soil had reached the desired moisture content, the box was packed with film paper and inserted into two tightly closed plastic bags in order to prevent the exchange of moisture with the medium, so that the suction was homogenously balanced throughout the volume of soil.

In order to simulate the drying effect of the soil in a constant ambient temperature, after the compaction of the soil, the box of the tests in the "DP" scenario was placed inside the oven at a constant temperature of $30^{\circ} \mathrm{C}$. The loss of moisture was controlled through the difference between the initial and final mass of the box. The drying process was finished after the sample reached a moisture content of $18.75 \%$. Then the box was packed with film paper and inserted into two tightly closed plastic bags in order to prevent the exchange of moisture with the environment and to balance the suction of the soil through the box.

\section{Calculating the Confined Stiffness}

In order to use the geosynthetics as a reinforcement for pavements, the initial stiffness of the system from a pullout stress becomes more representative than the maximum pullout resistance. The reinforced pavement design methods, such as French Geotextile Committee (1981), Giroud and Han (2004) and the Swiss Society of Geotextiles Professionals (1985), for 




FIGURE 3 | Exhumation of non-woven geotextile after Pullout Test: (a) with reinforcement (b) without reinforcement.

example, use the tensile strength and the unconfined stiffness (Jn) of the geosynthetic as a design parameter.

As the reinforcement used in the work is in a confined system, the mechanical behavior of the geosynthetic inserted in the pavement structure differs from that observed in tensile strength tests. Thus, it is assumed that the geogrid deformations in a field situation are smaller than those obtained in unconfined tensile tests.

During the pullout test, readings of the tensile load and displacements along the geosynthetic were made by the load cell and the four tell-tales, respectively. The apparent confined deformation was obtained by the displacement difference between the sensors called D2 and D3 (Figure 2), whose initial relative distance is $4.5 \mathrm{~cm}$.

Although the pullout test is not the most suitable test for this calculation, the criterion for obtaining the confined stiffness modulus (Jc) was defined as the ratio between the pullout force and the deformation of the geosynthetic between two sensors, as an approach for a quantitative analysis (Equation 1).

$$
J c=\frac{\text { Pullout Force }\left(\frac{\mathrm{kN}}{\mathrm{m}}\right)}{\text { Deformation between } D 3 \text { and } D 2(\%)}
$$

Ferreira et al. (2008) used the same method and the same pullout apparatus to obtain the confined stiffness of geogrids and woven geotextiles. Moraci and Recalcati (2006) and Cardile et al. (2016) used a similar approach, where the slope of the curves of displacement $v$ s. position along the specimen represented the local strain.

Geosynthetics are extensible reinforcements whose deformation in the confined region usually is larger in the frontal zone and smaller at the bottom of the box. However, for short inclusions, due to the extensibility effect, the distribution of the displacement, and therefore, of the shear stress was almost uniform along the length of the reinforcement (Cardile et al., 2016). The purpose of the pullout test is not to take the geotextile to rupture. The test would not simulate the confinement throughout the geotextile for large displacements, since the pressure bag would act in a limited area of the sample. With the pullout test, we intend to study only the load-elongation behavior of the confined geotextile at low deformations, as in geotextile-reinforced pavements, deformation greater than $2 \%$ was not observed (Lanz, 1992; Martins, 2000; Mendes, 2006).

Fannin and Raju (1993) used strain gages to check the longitudinal deformation along the geosynthetic. Authors such as Palmeira (2009), Ferreira and Zornberg (2015), Bathurst and Ezzein (2017), and Zornberg et al. (2017) also presented different proposals and more complex approximations for the calculation of the confined stiffness of the geosynthetics using pullout tests. These approximations appear to be significantly better for the calculation of confined deformation of the geotextile than the calculation of the deformations directly by the displacement between two consecutive points.

\section{RESULTS AND DISCUSSION}

Figure 4 illustrates the behavior of the unconfined stiffness modulus curves and deformation of the non-woven geotextile. Unconfined stiffness was obtained by the ratio of tensile force and deformation between two points known in the wide-width tensile test (ABNT NBR ISO 10319, 2013). The curves did not present considerable variability between the specimens.

Figure 5 shows the pullout test curves with the non-woven geotextile in the Optimum Scenario (O) with an overload of $14 \mathrm{kPa}$, as well as its suction measured by the tensiometer. It can be observed that the closer to the frontal region of the box, the greater the displacements of the transducers. As expected, all the tests presented the same behavior pattern as the sensors. The suction showed a slight variation after reaching the maximum pullout strength.

Figure 6 shows the curves obtained by the average displacements of the tell-tales in the pullout tests, as well as their suctions.

Figure 7 shows the comparison between $\mathrm{J}_{N}$ (unconfined stiffness modulus) and $\mathrm{J}_{C}$ (confined stiffness modulus) of the non-woven geotextile used under different scenarios. In these charts, the Jn curve was that of the specimen that provided the intermediate values among the four specimens tested at the 




FIGURE 4 | Unconfined stiffness modulus curves of the wide-width tensile test.

wide-width tensile test. The results presented stiffness curves with the same order of magnitude as the curves obtained by Ferreira et al. (2008) tested in the same small scale apparatus, but with granular soil in the upper layers. The curves obtained by Cardile et al. (2016), even using large boxes and an extruded geogrid with nominal tensile strength of $60 \mathrm{kN} / \mathrm{m}$ and vertical pressure of $50 \mathrm{kPa}$, also presented the same order of magnitude of the stiffness.

According to Figure 7, the tests in the "D" Scenario presented the greatest increase of stiffness caused by the overload, which agrees with the results obtained in marginal soils by

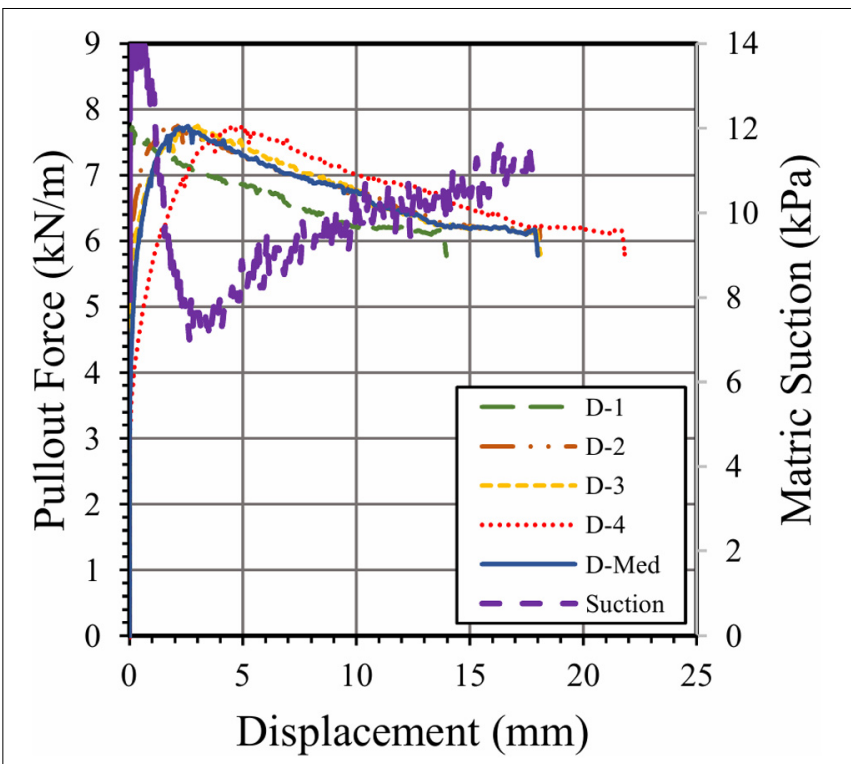

FIGURE 5 | Pull-out curves for different points along the geosynthetic and suction measured by the tensiometer (Condition O-14).

Esmaili et al. (2014) and Portelinha et al. (2018), where the tests directly compacted at a moisture content lower than the optimum moisture content presented better performances than the tests in the Optimum Scenario. The confined stiffness was not evaluated in these works. Esmaili et al. (2014) suggested a possible influence of the soil structure in soils initially placed and compacted at the dry moisture content (D Scenario).

The "DP" and "O" scenarios presented a similar stiffness curve behavior for the two overloads. However, the "DP" Scenario has a higher matrix suction than "O" by the drying process and greater confined stiffness curves were expected, similar to the "S" Scenario presented (tested with the same suction). This may
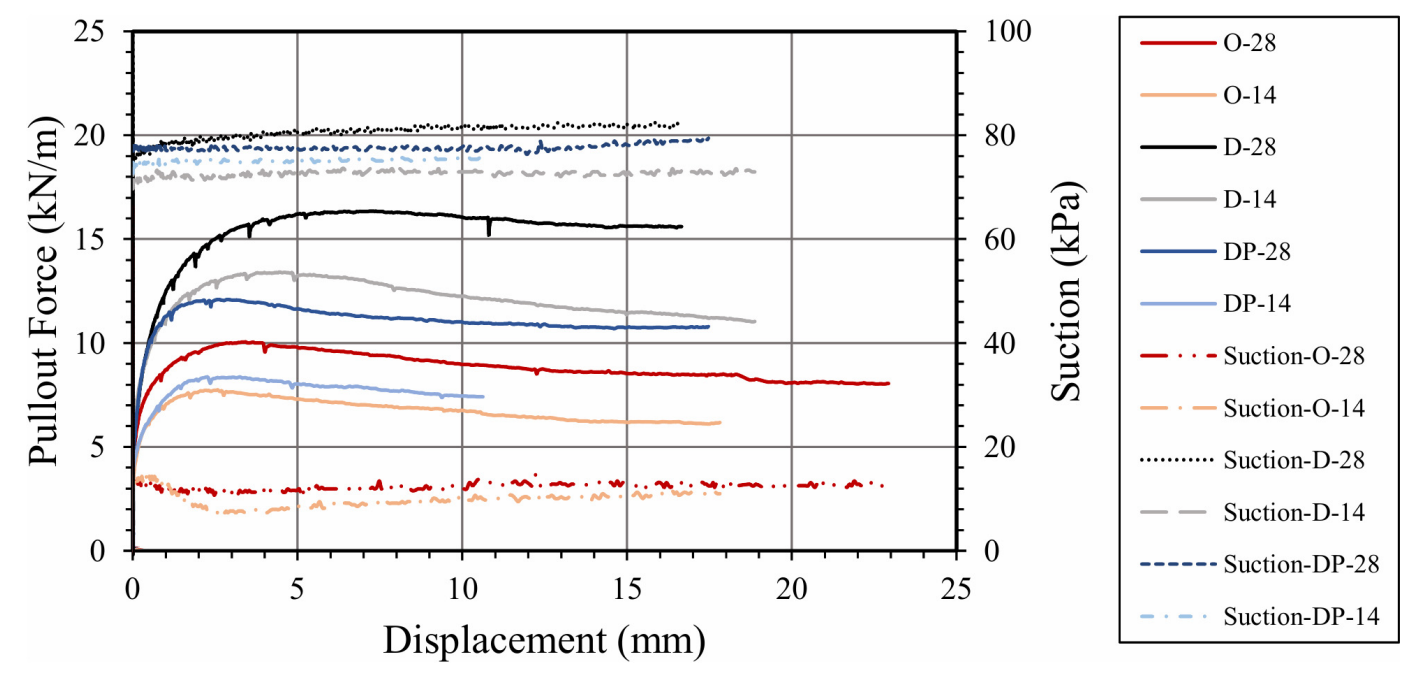

FIGURE 6 | Average displacement pull-out curves and their suction. 

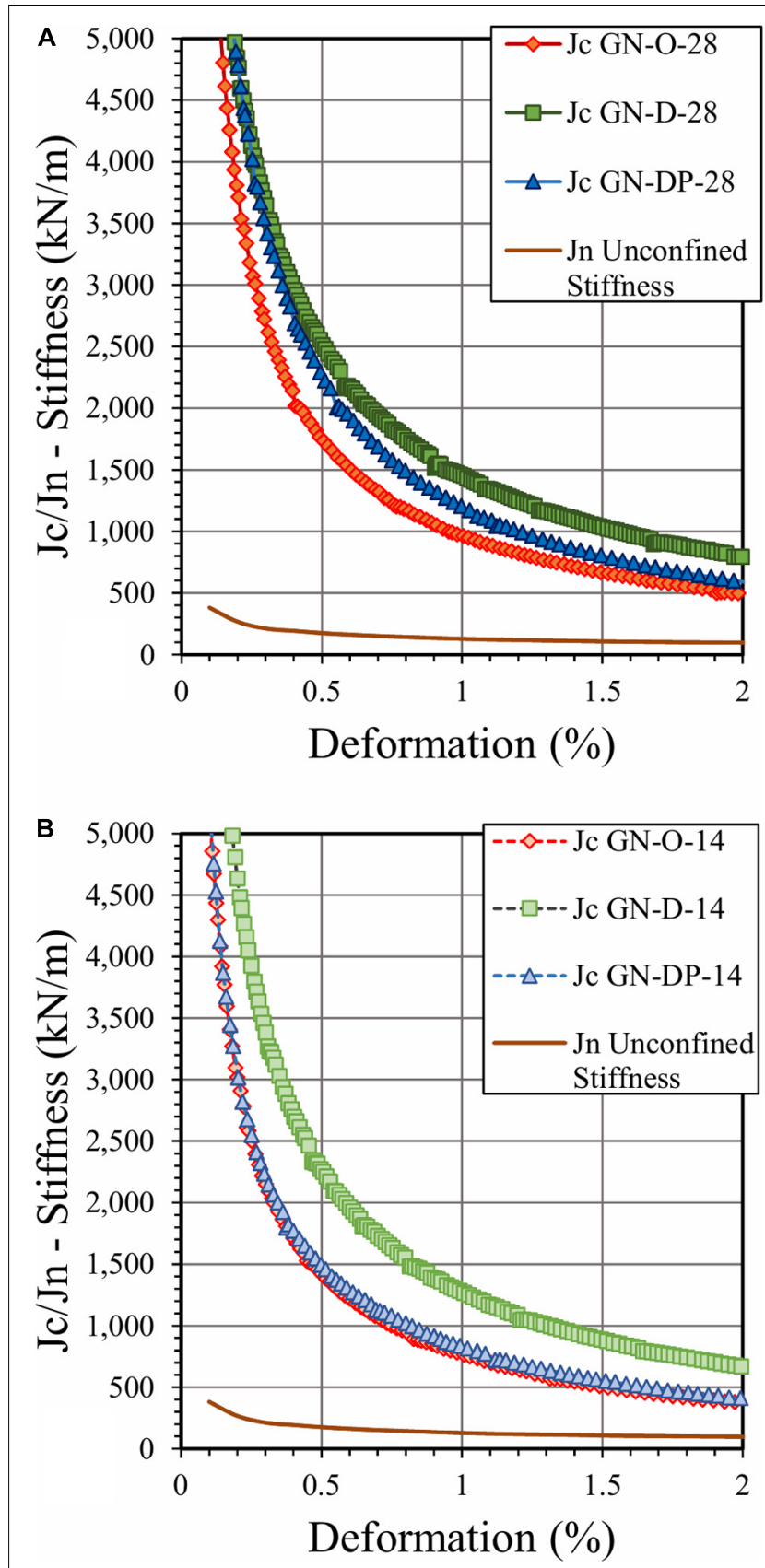

FIGURE 7 | Comparison between confined and unconfined stiffness under different scenarios for the overload of: (a) $28 \mathrm{kPa}$ and (b) $14 \mathrm{kPa}$.

indicate the existence of other parameters involved in non-woven soil-geotextile interaction, such as soil structure or compaction energy, which may influence interface resistance even more than soil matrix suction itself, as suggested but not verified by Esmaili et al. (2014). The quantification of these parameters requires a parametric statistical analysis of the pullout tests, which does not contemplate the main objectives of this work.

Jotisankasa and Rurgchaisri (2018) investigated a geocomposite with marginal soils in controlled suction direct
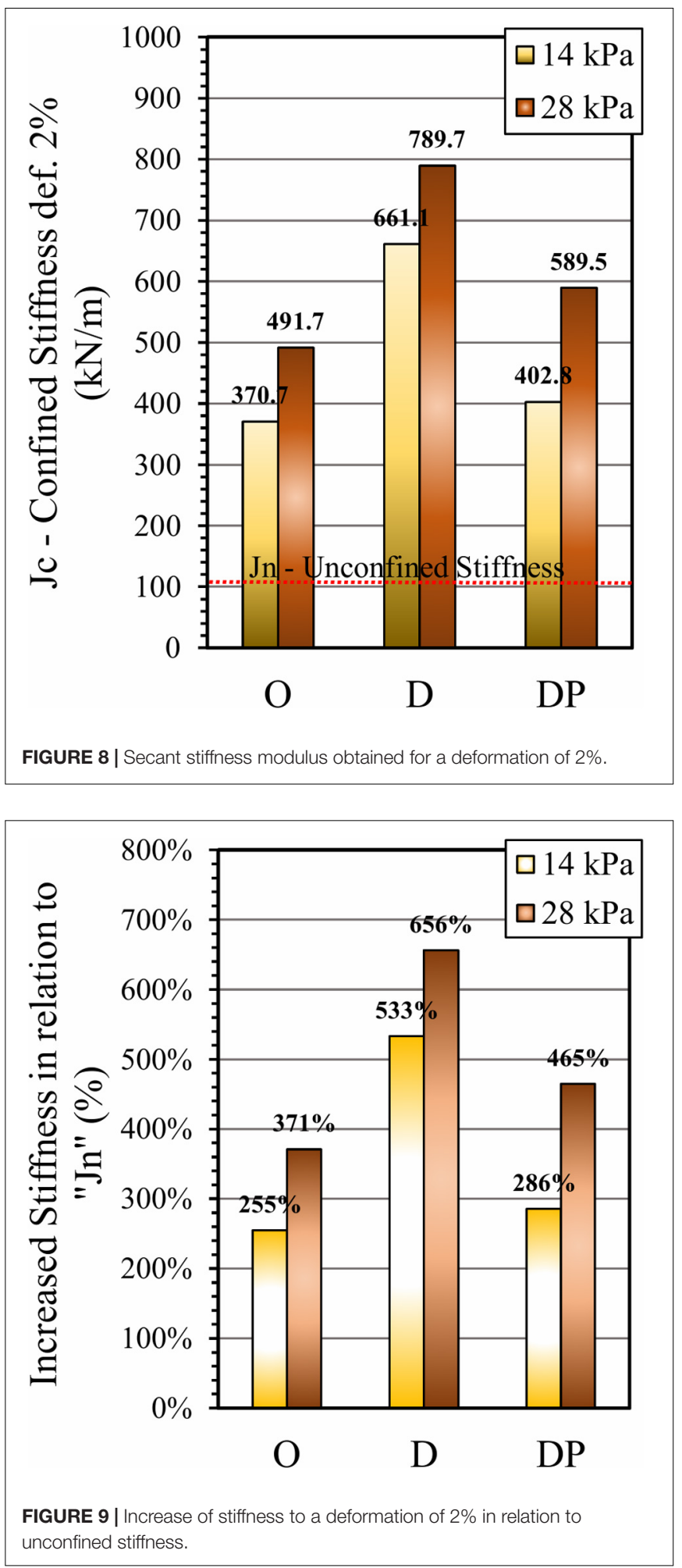

shear tests. In the sample preparation, the soil was compacted at the optimum moisture content with a subsequent drying process (DP scenario). The results showed a small increase in strength with suction (less than $<15 \%$ ) for $\mathrm{MH}$ and $\mathrm{CH}$ soils, which agrees with the results reported in the DP scenario of 
the present research for pullout tests. The $\mathrm{D}$ scenario was not investigated by Jotisankasa and Rurgchaisri (2018).

Based on the secant stiffness modulus for a $2 \%$ deformation, usually required for engineering designs, Figure 8 illustrates that all scenarios (O, D, and DP) presented a stiffness modulus above the unconfined stiffness, whose representation is given by the dashed horizontal line $(104.4 \mathrm{kN} / \mathrm{m})$. The increase in the overload provided an increase in the confined stiffness in all scenarios. The penetration of cohesive soil particles into the non-woven geotextile pores and the matrix suction at the interface of the geotextile, considered a draining material, are factors that may also have contributed to the increase in the confined stiffness of the geosynthetic. In the optimum scenario, Cardile et al. (2016) presented a magnitude of confined stiffness in the order of $800 \mathrm{kN} / \mathrm{m}$ for a $2 \%$ deformation, which was the same as unconfined stiffness.

Figure 9 illustrates the increase of secant stiffness in a $2 \%$ deformation in relation to the unconfined stiffness values "Jn." The "D" scenario in an overload of $28 \mathrm{kPa}$ presented a stiffness increase of $656 \%$. Even under low overloads, the lowest increase of stiffness presented was $255 \%$, which attests the best performance of non-woven geotextile under confined conditions.

\section{CONCLUSION}

This work evaluated the confined stiffness of a non-woven geotextile, under different molding conditions, using monotonic pullout tests. After comparing these results with the unconfined stiffness, the following conclusions are reached:

The "D" Scenario had a stiffness on average 50\% higher than the "DP" Scenario, both tested with the same suction of

\section{REFERENCES}

ABNT NBR ISO 10319 (2013). Geossintéticos - Ensaio de Tração Faixa Larga. Rio de Janeiro: ABNT.

ASTM D 6706-01 (2013). Standard Test Method for Measuring Geosynthetic Pullout Resistance in Soil. West Conshohocken, PA: ASTM International.

Bathurst, R. J., and Ezzein, F. M. (2017). Insights into geogrid-soil interaction using a transparent granular soil. Géotech. Lett. 7, 179-183. doi: 10.1680/jgele. 16.00191

Cardile, G., Moraci, N., and Calvarano, L. S. (2016). Geogrid pullout behavior according to the experimental evaluation of the active length. Geosynth. Int. 23, 194-205. doi: 10.1680/jgein.15. 00042

Chang, D. T., Wang, W. J., and Wang, Y. H. (1998). "Laboratory study of the dynamic test system on geogrid reinforced subgrade soil," in Proceedings of the International Conference on Geosynthetics, Atlanta, 967-970.

Esmaili, D., Hatami, K., and Miller, G. A. (2014). Influence of matric suction on geotextile reinforcement-marginal soil interface strength. Geotext. Geomembr. 42, 139-153. doi: 10.1016/j.geotexmem.2014.01.005

Fannin, R. J., and Raju, D. M. (1993). On the pullout resistance of geosynthetics. Can. Geotech. J. 30, 408-417.

Ferreira, J. A. Z. (2007). Estudo de Reforço de Pavimentos Com Ensaios de Arrancamento em Equipamento de Pequenas Dimensões. dissertation/master's thesis, University of São Paulo, São Carlos.
$75 \mathrm{kPa}$. It indicates that other parameters may be influencing the interaction between the soil and the geosynthetic, such as soil structure or changes in lateritic soil properties caused by the increase of compaction energy. A small increase of strength in DP Scenarios was also reported by Jotisankasa and Rurgchaisri (2018) in direct shear tests.

Although non-woven geotextiles are considered low stiffness materials and are often excluded as an option of reinforcement, these are presented as a favorable material when confined. In addition, in drier scenarios, typical in lateritic pavements, the geotextile also has an increase of stiffness. However, a larger number of tests, as well as additional analyses in real case studies, are needed to validate this statement in the field. In any case, the use of unconfined stiffness of non-woven geotextiles in projects can be considered a conservative attitude.

\section{DATA AVAILABILITY STATEMENT}

The datasets generated for this study are available on request to the corresponding author.

\section{AUTHOR CONTRIBUTIONS}

All authors listed have made a substantial, direct and intellectual contribution to the work, and approved it for publication.

\section{FUNDING}

The authors are grateful for the financial support received from the CAPES.

Ferreira, J. A. Z., Bueno, B. S., and Zornberg, J. G. (2008). "Pavement reinforcement study using small dimension pullout equipment," in Proceedings of the First Pan American Geosynthetics Conference \& Exhibition, Cancun, 963-972.

Ferreira, J. A. Z., and Zornberg, J. G. (2015). A transparent pullout testing device for 3D evaluation of soil-geogrid interaction. Geotech. Test. J. 38, 686-707.

French Geotextile Committee (1981). Recommendations Pour l'emploi Des Geotextiles Dans Les Voles de Circulation Provisoures, Les Voies a Faible Traffic et les Couches de Forme. Boulogne: Committee François des Geotextiles.

Giroud, J. P., and Han, J. (2004). Design method for geogrid-reinforced unpaved roads. I. Development of design method. J. Geotech. Geoenviron. Eng. 130, 775-786. doi: 10.1061/(asce)1090-0241(2004)130:8(775)

Jotisankasa, A., and Rurgchaisri, N. (2018). Shear strength of interfaces between unsaturated soils and composite geotextile with polyester yarn reinforcement. Geotext. Geomembr. 46, 338-353. doi: 10.1016/j.geotexmem.2017.12.003

Kakuda, F. M. (2005). Estudo de Ensaios de Arrancamento de Geogrelha Com Utilização de Um Equipamento Reduzido. dissertation/master's thesis, University of São Paulo, São Carlos.

Lanz, D. (1992). Estudo de Deformabilidade e Tensões em Estruturas de Arrimo em Solo Reforçado com Geotêxteis. dissertation/master's thesis, University of Brasilia, Brasília.

Martins, C. C. (2000). Análise e Reavaliação de Estruturas em Solos Reforçados com Geotêxteis. dissertation/master's thesis, Federal University of Ouro Preto, Ouro Preto.

Mendes, M. J. A. (2006). Comportamento Carga-Alongamento de Geotêxteis Não Tecidos Submetidos à Tração Confinada. dissertation/master's thesis, University of Brasilia, Brasília. 
Moraci, N., and Recalcati, P. (2006). Factors affecting the pullout behavior of extruded geogrids embedded in a compacted granular soil. Geotext. Geomembr. 24, 220-242. doi: 10.1016/j.geotexmem.2006.03.001

Nogami, J. S., and Villibor, D. F. (1981). "Uma nova classificação de solos para finalidades rodoviárias," in Proceedings of the Simpósio Brasileiro de Solos Tropicais em Engenharia, Rio de Janeiro, 30-41.

Palmeira, E. M. (2009). Soil-geosynthetic interaction: modelling and analysis. Geotextext. Geomembr. 27, 368-390. doi: 10.1016/j.geotexmem.2009.03.003

Portelinha, F. H. M., Pereira, V. R. G., and Correia, N. S. (2018). Small-scale pullout test of a geogrid-reinforced unsaturated soil with suction monitoring. Geotech. Test. J. 41, 787-804. doi: 10.1520/GTJ20150182

Swiss Society of Geotextiles Professionals (1985). Le Manuel des Geotextiles. Association Suisse des Professionels des Geotextiles. Dübendorf: EMPA.

Vilar, O. M., and Bueno, B. S. (2008). "Some topics regarding the influence of nonsaturation on the behavior of reinforced soil structures built with tropical soils," in Proceedings of the First Pan American Geosynthetics Conference \& Exhibition, Cancun, 272-280.
Villibor, D. F., Nogami, J. S., Cincerre, J. R., Serra, P. R. M., and Neto, A. Z. (2009). Pavimentos de Baixo Custo para Vias Urbanas, $2^{\mathrm{a}}$ Edn. São Paulo: Arte \& Ciência.

Zornberg, J. G., Roodi, G. H., and Gupta, R. (2017). Stiffness of soil-geosynthetic composite under small displacements: I. Model development. J. Geotech. Geoenviron. Eng. 143:135153460. doi: 10.1061/GT.1943-5606.0001768

Conflict of Interest: The authors declare that the research was conducted in the absence of any commercial or financial relationships that could be construed as a potential conflict of interest.

Copyright (c) 2020 Marques and Lins da Silva. This is an open-access article distributed under the terms of the Creative Commons Attribution License (CC BY). The use, distribution or reproduction in other forums is permitted, provided the original author(s) and the copyright owner(s) are credited and that the original publication in this journal is cited, in accordance with accepted academic practice. No use, distribution or reproduction is permitted which does not comply with these terms. 